\title{
DEMOCRACY AND REPRESENTATION: A CRITIQUE OF MORTON AND KNOPFF
}

\section{ALLAN TUPPER*}

In a reply to Morton and Knopff, who argue against "one person, one vote." the author challenges a number of arguments central to their paper. Their reliance on historical practices and traditions, for example, is criticized for they fail to take into accoumt serious contemporary challenges to the legitimacy of those practices and traditions. Their conception of "communities of interest" and their reliance on the absence of an elected upper house as reasons to trump voring equality rights is also questioned. The author argues that Morton and Knopff's static and conservative view of Canadian democracy should be supplanted with more democratic alternatives founded on the principle of voter equality.
Dans la réponse adressée à Morton et à Knopff. qui s'élèvent contre le principe $d$ "une personne, une voix", lauteur remet en question un certain nombre d'arguments essenticls. II critique, par exemple, le fait qu'ils s'apputient sur des pratiques et traditions historiques sans tenir compte de tout ce qui. aujourd'hui, conteste leur légitimité. Il s'élève également contre la notion quils ont des "communautés d'intérêts" et contre le fait qu'ils invoquent l'absence d'un Sénat élu pour supplanter les droits à l'égalité de vote. L'auteur déclare que les points de vue statiques et conservateurs que Morton et Knopff ont de la démocratie canadienne devraient faire place à des notions plus démocratiques fondées sur le principe d'égalité des électeurs.

\section{TABLE OF CONTENTS}

I. INTRODUCTION ......................695

II. THE RELEVANCE OF HISTORY AND

FEDERAL PRACTICE . . . . . . . . . . . . . . . . . . . 697

III. REPRESENTATION AND POLITICAL INSTITUTIONS:

THE RELEVANCE OF BICAMERALISM . . . . . . . . . . . 699

IV. CONCEPTIONS OF CANADIAN DEMOCRACY . . . . . 701

V. THE SIGNIFICANCE OF COMMUNITY OF INTEREST $\ldots \ldots 703$

VI. A POSITIVE CASE FOR VOTER EQUALITY $\ldots \ldots \ldots \ldots \ldots 705$

VII. CONCLUSIONS $\ldots \ldots \ldots \ldots \ldots \ldots \ldots \ldots \ldots \ldots \ldots \ldots \ldots \ldots$

\section{INTRODUCTION}

The Canadian political system seldom directly confronts fundamental questions about the nature of political democracy. But stimulating recent debates about how best to construct electoral boundaries are an important exception to this general tendency. They raise basic questions about representation, about the significance of the franchise, and, most importantly, about the essence of a functioning democracy. Judicial decisions and continuing political debate about these matters in the 1990s will exert long-term influences on the development of representative democracy in this country. In my view, such debates, far from being divisive or alarming, reflect the emergence of a more mature,

Department of Political Science, University of Alberta. 
more sophisticated and more thoughtful Canadian democratic tradition. The spate of recent constitutional challenges to the principles and practices of provincial electoral machinery are the first salvo in a struggle that will persist throughout the decade. Our representational agenda will lengthen, not shorten. The courts, political parties, citizen groups, and governments will be engaged in the resolution of vexing questions.

My purpose in this essay is to challenge the central arguments of Professors F.L. Morton and Rainer Knopff in their paper entitled "Does the Charter Mandate 'One Person, One Vote'?" Their essay raises important issues about the Charter's impact on the construction of electoral boundaries. But it goes far beyond that topic and raises questions about the nature of representative democracy in modern Canada. I argue that Morton and Knopff unduly stress the need to weaken the core democratic principle of "one person, one vote" through the application of non-equality factors in the construction of electoral boundaries for both Parliament and the provincial legislatures. Morton and Knopff's argument is based on questionable assumptions about the role of historical factors, an overly benign interpretation of recent federal experience, and a suspect effort to justify non-equality factors in the construction of electoral boundaries by strained references to the absence of elected upper houses in Parliament and the provinces. In response, I argue that to the extent that vague, non-equality principles like the representation of "places" are relevant, Canadian governments can and do accommodate them in several ways without eroding the principle of "one person, one vote." I further contend that Morton and Knopff's arguments flow from a dated and static view of Canadian democracy, one that is deeply conservative in its distaste for majority rule and one that ignores strong historical and contemporary democratic impulses.

The issues at stake are of more than academic importance. As noted earlier, complex problems of representation will remain indefinitely controversial in democracies. Moreover, Morton and Knopff's arguments, as embodied in a larger study, ${ }^{1}$ formed the intellectual core of the Alberta government's defence of the 1990 Electoral Boundaries Commission Act whose major provisions were deemed constitutional by the Alberta Court of Appeal in its 1991 ruling. $^{2}$ The ideas expressed herein are thus parts of a contemporary debate within Alberta and Canada.

My second argument is a positive one. I contend that the "right to vote," to be meaningful in a democracy, must embrace the principle of "one person, one vote" at the ballot box. The formal equality of citizens, as represented by the ideal of "one person, one vote," is a central democratic principle. But in practice, this basic value is deeply eroded in modern democracies by substantial economic inequalities between citizens, by the power of organized interests, and by the growing influence of experts in decisionmaking. Given that such powerful forces are not amenable to easy alteration by

1. F.L. Morton and R. Knopff, "The Right to Vote, Electoral Distribution and Boundary Adjustment in Alberta" (Department of Political Science, University of Calgary, 1991) [unpublished].

2. Reference Re The Electoral Botndaries Commission Act (21 November 1991), Edmonton 9103-0081AC. 
governments, the state must not sponsor initiatives that limit further our already tenuous political equality.

\section{THE RELEVANCE OF HISTORY AND FEDERAL PRACTICE}

Morton and Knopff accept, albeit often grudgingly, that voter equality is an important criterion for the construction of electoral boundaries in a modern democracy. But their thesis is that equality must be significantly compromised by non- equality factors. In advancing their case, the authors maintain that curbs on voter equality are justified by historical traditions which allow non-equality factors to play a prominent role in the construction of electoral boundaries. But their appeal to history and tradition is neither instructive nor deeply significant. For the authors advance no powerful argument about why historical practices, some of them dating from the nineteenth century, remain relevant. Historical dilutions of voter equality, in and of themselves, establish no powerful basis for contemporary practices. Are historical practices always and necessarily appropriate to modern conditions?

In their efforts to demonstrate historical lessons, Morton and Knopff rely heavily on federal government practices and political history. Among other things, they argue that the interprovincial distribution of seats in the House of Commons reflects an acceptable historical tempering of the "representation by population" principle. Against this claim, two points can be made with certainty. First, evidence of growing interprovincial inequalities in the allocation of Commons seats, far from being an argument for inequality at the provincial level, is a deeply worrying trend in Canadian democracy. Second and more generally, one must question the relevance of applying principles (especially suspect ones) from the federal level to provincial politics. The allocation of Commons seats between the provinces raises complex but well-known problems about how best to construct national government institutions in a federal state. Such questions, although very important, are unique to the national level. They have no provincial parallels. In the same vein, Morton and Knopff's claim that the principles underpinning Canada's constitutional amending formula are relevant to the debate about electoral boundaries is creative but far-fetched.

For unspecified reasons, Morton and Knopff imply that current federal practice is a norm against which provincial laws can be measured. They assert that federal laws and practices governing both the interprovincial and intraprovincial allocation of seats are acceptable dilutions of voter equality. Without argument, they accept Ottawa's norm of plus or minus twenty-five percent of the provincial quotient as a suitable basis for intraprovincial boundary construction. Controversial amendments in 1985 to allow for even greater intraprovincial disparities are not critically examined. In short, the authors' account of the federal experience merely demonstrates that voter equality is not a paramount objective. But their reference to the national experience advances no clear arguments about why dilutions of voter equality are either necessary or desirable. 
Morton and Knopff speak glowingly about the capacity of the federal government's system to reconcile competing representational principles. But does close analysis of recent federal experience establish grounds for optimism? The scholarship of Professor John Courtney, an acknowledged expert on Canadian representation, is quoted frequently and favourably by the authors. ${ }^{3}$ But a careful reading of Courtney's work reveals his deep concerns about such troubling developments as the continuing erosion of "rep by pop," mounting political attacks on the independence of the provincial boundary commissions, and grave continuing problems for the commissions in balancing conflicting principles in the intraprovincial allocation of seats.

The sole glimmer of hope in Courtney's otherwise unhappy assessment - his sense that intraprovincial inequalities are eroding - is disputed by Professor Andrew Sancton. ${ }^{4}$ Sancton's thorough assessment of recent federal experience is, like Courtney's, pessimistic. But he also argues that intraprovincial inequalities are increasing and that the 1985 amendments will probably produce greater future inequalities as commissions are pressured to recognize more "special cases" that exceed the twenty-five percent limit. He notes that the recent Newfoundland experience resulted in the construction of federal ridings where the most heavily populated seat has three and one-third times as many residents as the least populated one.

Both experts conclude that the extant federal system, far from being a democratic utopia, faces serious challenges to its legitimacy. Indeed, both worry that the 1985 amendments, by conferring further discretion on the commissions to exceed the twentyfive percent limit, place new, more intense and conflicting pressures on the provincial commissions. In Sancton's words: "The work of electoral boundaries commissions is made infinitely more difficult by having this additional authority - so much so that it is difficult to imagine them surviving long in the existing form." ${ }^{5}$ Both Courtney and Sancton predict significant future judicial interventions.

It is in this controversial and confusing context that we must evaluate Morton and Knopff's claim that the federal experience is a suitable yardstick by which to evaluate provincial initiatives. In this vein, their remarkable comment that "the more politically significant criticism has been that representation in the House of Commons is too responsive to population" is not sustained by evidence. Moreover, by what criteria does one decide whether an argument is more or less "politically significant"?

3. J.C. Courtney, "Parliament and Representation: The Unfinished Agenda of Electoral Redistributions" (1988) 21 Canadian Journal of Political Science 675.

4. A. Sancton, "Eroding Representation by Population in the Canadian House of Commons: The Representation Act, 1985" (1990) 23 Canadian Journal of Political Science 441.

Ibid. at 455. 


\section{REPRESENTATION AND POLITICAL INSTITUTIONS: THE RELEVANCE OF BICAMERALISM}

Morton and Knopff emphasize the structure of national government institutions as a basis for establishing representational principles for the conduct of federal and provincial general elections. Their case rests on the dubious proposition that the absence of an elected national Senate (presumably, but not necessarily, of the so-called "Triple E" variety) and similar institutions in the provinces somehow establishes grounds for the application of non-equality factors in the construction of electoral districts. Their assertions about upper houses play another important role in their argument. They employ them as a basis for dismissing recent American trends towards "one person, one vote." Put simply, Morton and Knopff claim that the extant American Senate, embracing as it does democratic election but not "rep by pop," allows the rigorous application of voter equality in the House of Representatives. In Canada, by contrast, the absence of such upper houses demands that voter equality be compromised by non-equality factors. They emphasize the elusive idea of "representation of places" which is ultimately their cardinal representational principle and one which must trump voter equality.

To restate an earlier argument, serious political and constitutional analysis demands a consistent distinction between the principles prevailing in the construction of national institutions in a federal state and those prevailing at the provincial level. The imperatives of maintaining a "federal bargain" demand that careful and continuing attention be paid to the representation of regional, linguistic, ethnic, and social groups within important national institutions. National governments in modern federations respond to such pressures in several distinct ways. But even assuming that an elected, federal Senate is desirable, does its absence really have clear implications for the construction of electoral boundaries? Are bicameral legislatures, especially provincial ones, necessary conditions for the construction of electoral boundaries that give proper weight to voter equality?

Another important question arises. Does the absence of elected upper houses demonstrably weaken the representation of "places" or impede the articulation of territorial interests in Canadian politics either nationally or provincially? In this context, one must recall that in postwar Canadian politics the trend has been toward a model of "interstate" federalism. That is, regional tensions and indeed most major policy matters are now decided through formal negotiations between the federal and provincial governments rather than within national institutions. In the vitally important institution of First Ministers' Conferences, the premier of the smallest province sits as an equal with the Prime Minister and the premiers of the heavily populated provinces. Does such an institution not temper significantly the principle of "rep by pop"? Does "executive federalism," to employ the generic phrase, not give enormous recognition to the territorial dimension of Canadian 
political life? ${ }^{6}$ Similarly, the constitutional convention of regional representation as a prime criterion in the construction of federal and provincial cabinets is further powerful evidence of the abiding recognition of "place" in Canadian politics. Such institutional and constitutional measures are now supplemented by a range of practices at both levels of government including the decentralization of administrative agencies, regional representation as a criterion for the makeup of government advisory boards, and the establishment of government agencies and economic and social programs tailored to particular regional needs. As Professor Richard Simeon maintains, the operation of such basic Canadian political institutions as cabinet government, the electoral system and federalism reinforces the political significance of place in our political discourse, in our policy-making and in our definition of political problems. ${ }^{7}$ In his view, the institutional context of Canadian government reflects underlying territorial diversities but also shapes them, highlights their particular characteristics, and gives them greater political significance than they would enjoy under alternative institutional structures. In short, the political apparatus exerts an independent effect on our political life. In Canada, its principal contribution is to highlight regional and territorial diversities and to reduce the political significance of such important, non-territorial cleavages as social class, gender, and ethnicity.

Place already enjoys an exalted status in Canadian politics and society. Past and present governments have responded to territorial diversities through the deployment of an arsenal of policy tools and administrative practices. Given the existing range of response to place, why should we weaken the core value of "one person, one vote" to give further weight to territorialism? In this vein, Morton and Knopff conveniently ignore how technological changes, especially communications technologies and the improvement of transportation systems, undercut the standard defence of non-equality factors in the construction of electoral boundaries. In modern democracies, elected representatives have at their disposal communication and transportation facilities scarcely dreamed of even two decades ago. In Alberta, for example, the construction of improved highways, the building of more and better airports, and the installation of sophisticated communications systems are long-standing provincial government priorities. ${ }^{8}$ Under these circumstances, the claim that electoral boundaries must be cast to recognize the particular problems of representatives from outlying regions loses its urgency. Governments now have at their disposal many policy responses to the various problems faced by legislators in the performance of their duties. Distance allowances, travel stipends, research services, and funds for communications and offices, to name just a few, are measures that legislatures

6. It is worth noting that Peter Lougheed, a former premier of Alberta and a powerful spokesperson for western Canadian interests, opposed a reformed Senate for many years because of his concern that it would erode the position of provincial governments as the principal spokespersons for regional and provincial interests.

7. R. Simeon, "Regionalism and Canadian Political Institutions" (1975) 82 Queen's Quarterly 495.

8. For details see A. Tupper and G.B. Doern, "Alberta Budgeting in the Lougheed Era" in A.M. Maslove, ed., Budgeting in the Provinces: Leadership and the Premiers (Toronto: Institutc of Public Administration of Canada, 1989) 121. 
may employ to increase the effectiveness of their members. Such policies are superior alternatives to the construction of electoral boundaries on the basis of non-equality principles.

\section{CONCEPTIONS OF CANADIAN DEMOCRACY}

Professors Morton and Knopff are not powerful defenders of political equality. On several occasions, they disdainfully dismiss the fundamental democratic principle of "one person, one vote" as the "simple counting of heads." They laud the British experience where the "representation of places" trumps "the representation of people." They conveniently ignore the Australian experience which demands substantially greater respect for "one person, one vote" than either Canadian or British practice. In this context, they also ignore the basic similarities between Australian and Canadian development. Both are large, relatively sparsely populated, former British Dominions with uneven internal distributions of population across large distances. Both are now fully autonomous federal democracies operating within British parliamentary traditions. Morton and Knopff also employ hyperbole when describing the recent American experience with "one person, one vote" as one allegedly leading to a nearly anarchical orgy of gerrymandering. They ignore the fact that such "political gerrymandering," whose American extent is not satisfactorily documented, is very difficult in Canada given our tradition of independent boundary commissions.

Such remarks betray a deeper philosophical and political position. For Morton and Knopff assert that Canada's political and constitutional order is anchored by an abiding distrust of republican ideas and a particular suspicion of unbridled majoritarianism. Our constitutional order, they maintain, properly embodies many severe restrictions on majoritarianism. Accordingly, it is entirely acceptable that majoritarianism be restrained even at the ballot box. The notion of "one person, one vote" must be tempered by nonequality factors. In their view, limitations on voter equality are congruent with the essence of Canadian democracy.

Several important counter-arguments arise. First, Morton and Knopff's implicit argument that "one person, one vote," if rigorously applied to the construction of electoral boundaries, will somehow lead to either a denial of minority rights or to a crude majoritarianism in policy-making is unfounded. Given the existence of competitive political parties, pressure groups, open elections and so on, there is no reason to believe that the construction of boundaries under the principle of "one person, one vote" will exert any predictable, let alone pernicious, influences on the course of democratic politics or the content of public policies. ${ }^{9}$ Second, and more importantly, Morton and Knopff assert that majoritarianism cannot be the exclusive criterion for the evaluation of democratic constitutions. Such a view is indisputably correct but ultimately irrelevant. For only one

9. The American experience with the "one person, one vote" principle sustains this argument. For details sce R.A. Hanson and R.E. Crew, Jr., "The Policy Impact of Reapportionment" (1973) 8 Law' and Society Review 69. 
aspect of the constitution is at issue - the meaning of the "right to vote" and the particular question of how far, if at all, non-equality factors should temper political equality in the construction of electoral boundaries. In this vein, their survey of the many checks on majority rule in Canada provides powerful evidence that further restraints on democracy, especially at the ballot box through the construction of electoral districts containing vastly different numbers of electors, are not necessary. Their argument sustains, rather than weakens, the essential case for voter equality. They paint a picture of a political order armed, if anything, with an excess of shackles on majority rule. Do we need further restraints and if so, is the baliot box not the last place to exercise them? Are electoral boundaries really effective instruments for the protection of minority rights?

Morton and Knopff advance controversial policy proposals on the basis of a brief and partial interpretation of Canadian democratic traditions. They correctly note the conservative bent of some of our democratic traditions. But they ignore the historical and contemporary existence of different, ultimately competing, democratic ideals, ideals rooted in political equality, popular sovereignty, and direct democracy. The most obvious manifestation of alternative democratic ideals is found in the diverse populist movements that have often thrived in Canadian politics. As Professor Philip Resnick argues, such movements, which exert a continuing influence on our politics, have advocated direct democracy, group government in some instances, and co-operative principles in economic and social activities. ${ }^{10}$ As such, they provide ideological antidotes to the conservative principles described by Morton and Knopff. And in the modern era, innovative and iconoclastic conceptions of democracy abound. For example, the Reform Party echoes, in a modern guise, traditional populist appeals. In the aftermath of Meech Lake, elite domination of constitution-making is now widely and routinely challenged. Citizen demands for more direct control over their political lives are manifest in proposals for the expanded use of referenda and for the establishment of democratically elected constitutional assemblies. Both such ideas, which seem to enjoy considerable popular support, were viewed as challenges to Canadian ideals only a decade ago. Many citizens contend that democracy must mean more than casting a ballot every four years. The Canadian Charter of Rights and Freedoms also exerts a profound effect on our democratic life. Many citizens now proudly view themselves as "rights bearers," equal one to another and in control of governments rather than responsive to their whims."

Recent constitutional discourse powerfully reveals Canadians' changing ideas about representation. Some women's groups, for example, see a reformed Senate as a chamber that should abandon place as a representational criterion and substitute gender. Other groups have called for a realignment of provincial boundaries and the construction of new provinces, while large municipalities, uneasy with their position as provincial dependents, seek representation in new ways. Aboriginal government and our heightened sensitivity University Press, 1990) especially at 88-106.

II. For details see A.C. Cairns, "Citizens (Outsiders) and Governments (Insiders) in Constitution-Making: The Case of Meech Lake" (1988) 14 Canadian Public Policy special supplement 121. 
to the distinctive representational needs of natives add further complexity to the debate. The federal government's 1991 constitutional proposals and discussions in several provinces have raised to new prominence little-discussed ideas about "guaranteed" aboriginal representation in elected assemblies. The apparently more consensual politics of Canada's northern territories are receiving considerable contemporary attention as residents in the more densely populated provinces search for alternatives. Such developments reveal Morton and Knopff's arguments, rooted as they are in a simple "people versus places" dichotomy, as narrow and dated.

My point is to highlight Morton and Knopff's static and conservative view of democracy. The Canadian democratic landscape is dynamic and heterogeneous. Current trends, backed by powerful institutional forces like the Charter, reveal the emergence of new democratic ideals which stress greater citizen involvement and political equality. Democratic conservatism, which Morton and Knopff employ to justify a reliance on nonequality criteria in the construction of electoral boundaries, has never been unanimously embraced by Canadians. As citizens in Eastern Europe and the former Soviet Union struggle to achieve democratic governance, Canadians are also struggling to give fuller meaning to democratic ideals in this country. Debates about principles of representation must be placed in the modern context of ideological ferment, not in the nascent and limited democratic vision of nineteenth-century British North America.

\section{THE SIGNIFICANCE OF COMMUNITY OF INTEREST}

To this point, I have argued that Morton and Knopff's case, which calls for the routine use of non-equality factors in the construction of electoral boundaries, relies on a debatable conception of democracy, a questionable assessment of federal practice as a model, and suspect arguments about the importance of bicameral legislatures. My final criticism flows from their unrepentant acceptance of voter "community of interest" as a central and compelling non-equality factor.

Is "community of interest" important enough to justify deviation from the clear and central democratic ideal of "one person, one vote"? Is it a precise enough notion to guide the construction of electoral boundaries? Such questions are significant insofar as Morton and Knopff employ "community of interest" as the intellectual foundation for their ideas about the importance of "place" as a cardinal representational principle.

Morton and Knopff concede that "community of interest" is a decidedly vague concept. Indeed, they provide no criteria for the determination of local "communities of interest." As explained by Morton and Knopff, "community of interest" is a phenomenon that may be shaped by such diverse forces as race, ethnicity, and religion. If such factors are not broad enough, they also assert that "community of interest" may be "animated by economic and political interests." The latter criteria are almost infinitely elastic. Indeed, without sarcasm, one might legitimately ask whether any social forces exist that do not determine local "communities of interest." And without evidence, they assert that "rural" and "urban" citizens (however defined) differ significantly about important policy matters. 
Moreover, and again without evidence, Morton and Knopff portray democratic citizens as being politically animated by local issues. In their words: "Not unnaturally, most individuals are most concerned about the local problems that touch their everyday work and leisure." How does such a view of political behaviour explain the emergence of national, sometimes transnational, political movements in such areas as the environment, women's issues, and peace? And if, as Morton and Knopff assert, our primary political concerns are local, what then accounts for the perennially low voter turnout in municipal government elections?

Albertans, for example, in different parts of the province may sometimes disagree with each other about political matters. But surely infrequent or occasional conflict between residents of different communities about routine matters is not evidence of local "communities of interest." To be meaningful, the concept must embody enduring and intense regional conflict over significant policy matters. And perhaps more importantly, strong local interests, that is the "community of interest," must be powerful enough to transcend other common bases for political conflict in modern societies including social class, gender, and age to cite a few. "Rural" and "urban" citizens may indeed differ over some policy matters, but how do we know such differences are more important than their common interests in, for example, honest government, efficient public administration, or clean air? Is it likely that an impoverished single parent in a small town has an abiding "community of interest" with a millionaire in the same town? Are her interests not likely to be closer to those of others in the same economic and social circumstances regardless of their location within a province or a country? Such questions about the weight of local interests are important. They raise complex philosophical and empirical questions which are ignored by Morton and Knopff. Attachment to a locality may indeed be politically important, but they advance no compelling philosophical, political or social evidence that it is ever, or even frequently, of paramount importance. Their interpretation of "community of interest" provides no strong reason to dilute political equality at the ballot box. As the Alberta Court of Appeal stated in its judgment, a "community of interest," even if identifiable, need not result in a dilution of voter equality. As the court put it: "The right of effective representation for rural voters does not mean they are always and everywhere to have divisions with lower populations." ${ }^{\text {22 }}$

One may reject my arguments and simply return to Morton and Knopff's assertion that local "communities of interest," while not definable by objective criteria, are self-evidently important. Put differently, can we not simply assert that local "communities of interest," like the Loch Ness monster and the Abominable Snowman, obviously exist even if we cannot readily prove it? Such arguments are troubling in a democracy. Is it desirable to confer knowingly on such important bodies as federal and provincial electoral boundaries commissions the task of defining, without any criteria, the admittedly undefinable? Can such a significant public institution, when given a complex and possibly unworkable mandate, maintain its legitimacy when it fails to satisfy public expectations it has not 
itself created? Should we expect the commission to define and reconcile abstract notions like "community of interest"? By conferring such a mandate on the commissions do we not almost guarantee, as graphically demonstrated by recent federal experience, political criticism of their efforts and challenges to their independence? ${ }^{13}$

In their broader assessment of the Alberta legislation, Morton and Knopff speak glowingly about the "multi-municipality electoral district"14 (MMED). They see this device as a welcome innovation and one that introduces considerable flexibility to the task of constructing boundaries fairly. In making their case about the virtues of the MMEDs, the authors assert that they must be used "aggressively" and "innovatively" if they are to equalize the voting power of urban and rural voters. But the statute does not direct the commission to employ the MMED concept in any way. Their argument thus assumes that the commission will consistently behave in a particular way. More importantly, given their arguments about the importance of place and the existence of local "communities of interest," should allegedly conflicting rural and urban voters be combined in the "hybrid" ridings described by Morton and Knopff? Are there "communities of interest" or not?

\section{A POSITIVE CASE FOR VOTER EQUALITY}

To this point, I have stressed the shortcomings of Morton and Knopff's case. But my second argument is a positive one. I maintain that certain characteristics of modern democracy, some of which are briefly sketched below, combine to undercut our political equality. Such factors cannot be easily altered by democratic governments. As a result, far from further eroding our shaky equality, governments must champion equality at the ballot box and resist measures that dilute the principle of "one person, one vote."

Political equality, as captured by the notion of "one person, one vote," is a necessary, albeit minimal and certainly not sufficient, characteristic of a democratic society. We are equal before the law and equal at the ballot box insofar as each person has one vote and no citizen's vote counts more than that of any other. But I am describing a formal political equality. In practice, certain widely noted characteristics of modern politics seriously attenuate our formal equality. In this context, the Saskatchewan Court of Appeal in contemplating the "right to vote" correctly noted: "The voices of voters may be muted in a number of ways." 15 The court's point of reference was suspect electoral practices that excluded citizens from their rightful participation or eroded their formal equality. But my concern is about forces that operate beyond the formal political arena and reduce our political equality. The most noteworthy factor is the remarkable economic inequalities that coexist with our formal political equality. Affluent citizens have greater financial resources with which to pursue their political goals. Their affluence may also afford them greater time to devote to democratic participation. They have access to leaders that the

Supra, note 3.

Supra, note 1 at 8 and 37.

Reference Re The Electoral Boundaries Commission Act, S.S. 1989, c. E. 6.I and The Represemtation Act, 1989. S.S. 1989, c. R-20.2 (6 March 1991) Regina 639 at 12. 
rest of us do not enjoy. Similarly, the more affluent citizen is generally better educated and hence armed with another significant political advantage. The large modern corporation, as an institution with enormous significance for our economic well-being, enjoys extraordinary political influence. And the complex policies of the modern interventionist state, to be effective, require administration by expert bureaucracies in both government and the private sector. Technical expertise, while necessary for our effective governance, confers power and influence on the tiny minority that possesses it. Such widely employed technologies as public opinion polling and data analysis have generated a new political elite with direct and continuing access to democratic politicians at the highest levels. The modern mass media, once seen as a neutral reporter of political events and a check on governmental abuse of power, is now widely viewed as an unaccountable repository of enormous, independent political influence.

Such problematic features of modern politics, and I have listed only a few of them, have two common features. First, each is a serious practical obstacle to the achievement of political equality. Second, as I have already argued, each reflects a series of profound economic and political forces that are not easily shaped or altered by governments. In an era of rapid technological change, can we readily limit the power of bureaucracy and its attendant technical experts? Can a democratic government easily curb the political power of the mass media? Will deeply rooted economic inequalities soon be reversed?

In a democracy, the ballot box is the principal locus of our formal political equality. Moreover, it is also the best place for ordinary citizens to curb the power of wellorganized groups, the power of technical experts and the influence of the economically affluent. Further, governments themselves control the electoral process and its attendant machinery. In this area, unlike most of those noted above, reforms can be easily enacted. Under these circumstances, governments, far from diluting our formal equality by dubious non-equality measures, must champion the principle of "one person, one vote" as the dominant determinant of electoral boundaries. Political equality in the modern democratic state is already subject to enough severe challenges from forces beyond our control. Viewed in this context, the vast majority of citizens do indeed have a "community of interest," not in the celebration of questionable local particularisms, but in the aggressive and unifying pursuit of their formal equality in the polling booth.

\section{CONCLUSIONS}

In examining the principles and machinery for the construction of electoral boundaries in Saskatchewan, the Supreme Court of Canada has established the principle that "one person, one vote," while important, will not necessarily be the dominant principle in the drawing of electoral boundaries. Rather, non-equality factors are tolerable in the pursuit of the broader goal of "effective representation." ${ }^{\text {16 }}$ But the term "effective

16. A.G. Saskatchewan v. Carter (6 June 1991) 22345 at 4. 
representation" is a broad one that is probably amenable to competing interpretations and definitions.

In Alberta, the situation is still fluid even though the Court of Appeal has examined and approved, albeit cautiously, the principles underpinning the 1990 version of the Electoral Boundaries Commission Act. The situation in Alberta is particularly complex because the political debate and constitutional controversy emphasized the principles embodied in the boundaries commission legislation as revised in 1990. That is, the matter was referred to the Court of Appeal before the Electoral Boundaries Commission had drawn a revised map. At the time of writing in early 1992, the map has finally been drawn, and not unexpectedly the debate about the quality of representation and the construction of provincial electoral boundaries has again erupted. The commission's interim report has been released and will now be subject to public scrutiny and debate before its possible amendment and submission to the government. It can be safely said given recent experience in Alberta and other Canadian jurisdictions that strong political and possibly legal challenges will occur before a new electoral map for Alberta is in place. In the short term, the controversy will centre around the balance between "urban" and "rural" representation and about the interim report's proposals to place parts of the City of Edmonton in "hybrid" constituencies with a mixture of "urban" and "rural" voters.

But the future debate in Alberta and other jurisdictions will probably transcend such questions. For example, the Alberta Court of Appeal made the pertinent observation in its recent judgment that a major constraint in the extant legislation is the statutory restriction on the size of the legislature to 83 seats which must be allocated among competing interests and according to sometimes clashing principles. Is a legislature that is too small for the community it serves a substantial barrier to the achievement of "effective representation"? Such questions may be unpopular in the present climate of cynicism about political elites, the party system, and the role of government, but they merit careful scrutiny. And regardless of questions about the drawing of electoral boundaries, what about the impact on democracy of a "first past the post" electoral system with its well-known capacity to distort the relationship between citizens' votes and seats in legislatures? Put positively, is some form of proportional representation a necessary condition for the achievement of "effective representation"? Might referenda and plebiscites be seen, under specified circumstances, as integral to the achievement of democracy? Finally, as I suggested earlier, the present debate which highlights the tension between urban and rural voters may fade in importance to be replaced by complex arguments about gender, race, and ethnicity as representational principles. Where we live may become much less important as compared with who we are in the construction of representative assemblies and the conduct of democratic elections. Such substantial changes will not occur overnight. But Canadian political discourse now accepts ideas about aboriginal government and representation that only a decade ago would have been widely seen as heretical. The times are indeed "a changin'" and Canadian courts, scholars and politicians will face difficult challenges to the representative status quo for the foreseeable future. The resultant debates will necessarily be deeply partisan. But they must be underpinned by careful reflection about the quality of Canadian democracy as we enter a new century. 